ORTOFOTO 5. ĢZZF WMS - LG̣IA Latvijas 5. etapa ortofoto karšu mozaīka. http://kartes.geo.lu.lv (23.01.2017).

Markots, A., Zelča L. and Zelčs, V. (1989). Augsto purvu fenomens. Zinātne un Tehnika, 11.

Markots, A., Zelča, L. and Zelčs, V. (1993). Dinamiskie sūnekḷi. Latvijas daba: enciklopēdija. 2. sēj. Rīga: Gandrs, 20-21.

Nomals, P. (1930). Latvijas purvi. In: Putniņš, R. (ed.) G̦eogrāfiski raksti. Rīga: Latvijas Ģeogrāfijas biedrība, 1-40.

Romanov, V.V. (1968). Hydrophysics of bogs. Kaner, N. (ed.) Jerusalem: Program for scientific translations Ltd, Jerusalem. 1-299.

Silamiķele, I. (2010). Humifikācijas un ķīmisko elementu akumulācijas raksturs augsto purvu kūdrā atkarībā no tās sastāva un veidošanās. Promocijas darbs. Rīga: Latvijas Universitāte.

Zelčs, V. (1994). Augstā purva mikroreljefs. Enciklopēdija "Latvijas Daba”, 1.sēj. Rīga.

\title{
HUMIC SUBSTANCES AND THE POTENTIAL OF THEIR USE IN AGRICULTURE
}

\section{Humusvielas un to izmantošanas iespējas lauksaimniecībā}

\author{
Māris Kḷaviṇš, Jānis Šìre, Laura Kḷaviṇa \\ University of Latvia, Department of Environmental Science \\ maris.klavins@lu.Iv
}

\begin{abstract}
Most important properties of the major soil and peat organic component - humic substances have been compared, depending on their origin, including the isolation, basic properties, and recent concepts about the structure of humic substances. The influence of humic substances on plant growth has been re-assessed in light of the growing use of humic products in agriculture, and the most prospective areas for humus application have been evaluated. The properties of humic substances possibly influencing their impact on plant growth and, in general, their role in the environment have been analysed. Peat humic substances have substantial potential for use in agriculture.
\end{abstract}

Keywords: natural organic matter; agriculture; biological activity

\section{Introduction}

Humic substances (HS) are the main component of soil and peat organic matter (SOM), comprising up to $60-70 \%$ of content, but at the same time humic substances can be considered as one of the key elements in the bio-geo-chemical turnover of carbon, possibly being the most abundant of naturally occurring organic macromolecules on Earth $\left(2-3 \times 10^{10} \mathrm{t}\right.$ ) (Jones and Bryan 1998). As far as HS are able to interact with inorganic and organic substances, they act as carriers for the many influencing fluxes of elements in the environment. They also play an important role in the formation of fossil fuels and mineral deposits (MacCarthy 2001).

Humic substances are a general category of naturally occurring, biogenic, heterogeneous organic substances that can generally be characterized as being yellow to black in colour, of high molecular weight, and refractory (Aiken et al. 1985).

They consist of several groups of substances that, depending on their solubility, can be grouped as: humin which is the fraction of humic substances that is not soluble 
in water at any $\mathrm{pH}$; humic acid (HA) which is the fraction of humic substances that is not soluble in water under acidic conditions $(<\mathrm{pH} 2)$, but becomes soluble at greater $\mathrm{pH}$; and fulvic acid (FA) which is the fraction of humic substances that is soluble under all $\mathrm{pH}$ conditions (Aiken et al. 1985).

Humic substances have many functions in the environment (Figure 1) (Orlov et al. 2002). In soils they participate in the formation of soil structure, thermal regime, but interacting with dissolved substances they influence the accumulation and release processes of nutrients and trace elements. Humic substances considerably influence soil biota and especially microbial activity.

The interaction of humic substances with organic substances can change their properties and fate in the environment. The most important observed impacts are:

1. increased apparent solubility of non-ionic hydrophobic substances;

2. reduced solubility of ionic organic substances;

3. reduced volatility of organic substances;

4. modified chemical reactivity of organic substances in the environment;

5. changes in the rate of organic bio-accumulation in the environment;

6. increased association of organic substances with sedimentary phases and particulate matter (Kḷaviņš 1998).

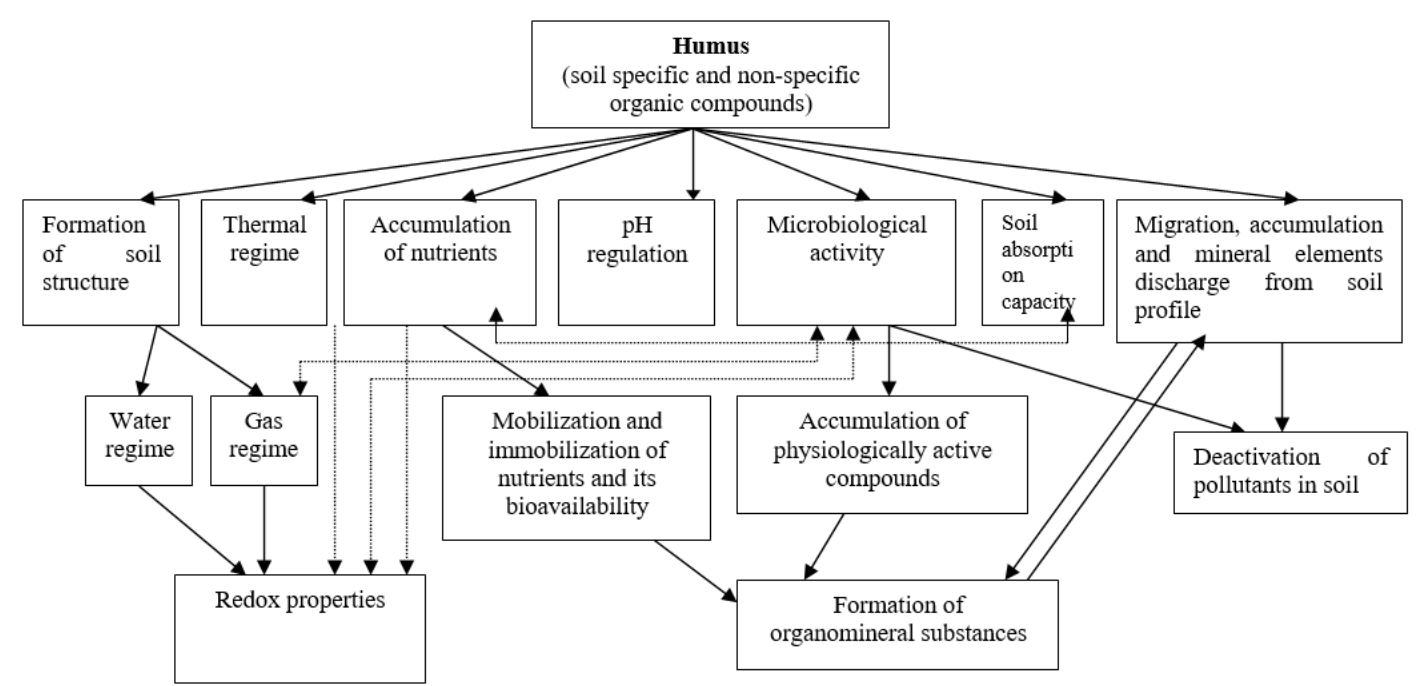

Figure 1. Roles of humic substances in environment (authors' figure using Orlov et al. 2002)

In general terms, humic substances may be considered as a matrix onto which environmental processes are imprinted, but, on the other hand, they can be considered as a reactive ingredient, actively participating in reactions and processes going on in the soil and aquatic environment. In so far as the major reservoir of humic substances are soils, they are an important factor in various areas of agriculture, such as soil chemistry, fertility, plant physiology and others. At the same time, humic substances can be considered as an important resource, as far as they may be extracted in industrial amounts from sources (soil, peat, coal and others) in which they are 
abundant and consecutively applied to achieve or increase their positive impacts. The various roles of humic substances in soil environments, and their possible use in agriculture has been examined in recent reviews (Nardi et al. 2002), but the area of their use is steadily growing and thus systematization of available knowledge can be important to develop the most rational ways of application and development of new roles.

Therefore, this paper aims to re-assess the areas of use of humic substances in agriculture, analysing the latest knowledge about the structure of humic substances, their functions in environmental processes, including their physiological effects, the character of interaction between humic substances and soil ingredients, nutrients, trace elements and other biologically active substances of importance for agricultural applications. This knowledge can be important considering recently developed technologies for humus extraction, many new applications of humic substances and the growing market of industrially produced humic substances.

\section{Isolation and basic properties of humic substances}

Humic substances are generally extracted from soil and peat by treating with alkaline solutions (Stevenson 1994) while humic and fulvic acids are solubilised, but the residue contains the humin. After the acidification of the alkaline extract by addition of a strong acid, humic acid precipitates the remaining organic material in the solution and is referred to as the fulvic acid (Stevenson 1994). Further purification is often needed to clean up the HA and to separate the FA from other materials in the fulvic acid fraction, as well as to reduce the ash contents of the humic and fulvic extracts, and to fully convert the acid salts to their hydrogen forms. Evidently quite a lot of chemical degradation occurs during the extraction of HS. Thus, base-extracted HS is generally a combination of native and altered materials. The extracted HS are frequently dried by conventional evaporation or by lyophilization. Many other extraction procedures and variations have been used, some involving various organic solvents such as dimethylsulfoxide, dimethylformamide, and formic acid (Hayes and Clapp 2001). It is not surprising that materials extracted from soils or sediments according to procedures based on the above definitions actually consist of mixtures, and their properties depend on the specific conditions of extraction. Nevertheless, there is a remarkable uniformity in the average properties of all HA, FA, and humins (Schnitzer and Khan 1972). The elemental contents of HA, FA from very different sources are remarkably consistent (Kḷaviņš 1998). Humic acids have been reported to have an average MW varying from about $800 \mathrm{Da}$ for aquatic materials to greater than $1 \times 10^{6} \mathrm{Da}$ for soil - and peat derived materials (Kḷaviņs 1998). Humic substances have an abundance of oxygen-containing functional groups (carboxyl-, phenolic-, alcoholic) which dominate their chemical properties. Humic substances occur in close association with other organic and inorganic materials in soil and sediments. Aquatic HS also occur in association with non-humic materials and may exist in colloidal or larger aggregate forms. 


\section{Interaction between humic substances, nutrients and trace elements}

The influence of soil humus on plant growth is much regulated through ion uptake, and these influences have been studied by Vaughan and Malcom (1985), Chen and Aviad (1990), Varanini and Pinton (2001). The effects of HS on ion uptake are more or less selective and variable in respect to their concentration and to the $\mathrm{pH}$ of the medium (Clapp etal. 1998). HS may stimulate $\mathrm{NO}_{3}{ }^{-}, \mathrm{SO}_{4}{ }^{-2}$ and $\mathrm{K}^{+}$uptake by barley and oat seedlings (Maggioni et al. 1987). The most significant stimulatory effect has been found considering $\mathrm{NO}_{3}{ }^{-}$uptake in oat roots.

The complexation of metals by humic substances is of particular interest because this complexation alters the toxicity and bio-availability of metal ions. The complexation of metals ions much reduce their toxicity in comparison with the free, hydrated metal ions (Florence and Batley 1980), however, substantial differences exist between different metal ions and the modification of metal ion toxicity depends also on properties of humic matter (Winner 1984). The interaction of humic substances with metals is important in plant nutrition and availability of metal ions as well as nutrients to plants in soils is a function of the speciation of the metals in the soil solutions surrounding the plant roots (Jarvis 1981). Considering the much differing toxicity and biological availability of different speciation forms it is thus important to consider not so much the total amount of metals, but rather their extractable forms (Alvarez et al. 2002). Humic substances exist both in the bound and in the dissolved phase. In the solid phase humic substances are present as coatings on mineral grains and possibly, in some instances, as separate particles. The most common type of interaction of metal ions with humic substances is ion exchange, in which protons on carboxylic acid groups are replaced by metal ions.

Most of the studies on the interaction of humic substances with anions have been concerned with the interactions of phosphorus species with humic substances as far as phosphorus is an essential plant nutrient. In the $\mathrm{pH}$ range of most natural waters and soils the predominant orthophosphate species in solution is $\mathrm{H}_{2} \mathrm{PO}_{4}{ }^{-}$. Orthophosphate reacts with $\mathrm{Fe}(\mathrm{III})$ and dissolved humic substances to form high molecular weight complexes (Francko 1986). At the present time, mechanisms of phosphorus cycling in the environment have not yet been clearly elucidated; however, it is apparent that $\mathrm{Fe}$ (III)-humic substances-orthophosphate complexes are an important part of this cycling.

\section{Interaction between humic substances and organic molecules of importance for agricultural plants}

Organic compounds interact with humic substances in a number of different ways. Non-ionic organic compounds partition into insoluble humic substances in soils, whereas soluble humic substances solubilize non-ionic organics (Wershaw et al. 1969; Chiou et al. 1983). Ionic organic compounds can undergo ionic exchange reactions and charge-transfer complexation. In addition, some evidence exists for oxidative coupling reactions between xenobiotic organic compounds and humic substances. The 
absorbtion of non-ionic organic compounds by wet soils involves partitioning of the organic compounds between the soil-water phase and the soil-organic phase. An analogous process to partitioning into an insoluble organic phase is the solubilization of hydrophobic organic compounds by dissolved humic substances. It has been found that humic acid enhances the solubility of DDT, but also of other hydrophobic pesticides in water (Misra et al. 1996). This increase in solubility is apparently brought about by the partitioning of the DDT molecules in the hydrophobic interiors of humic acid micelles. In a number of studies a variety of other hydrophobic organic compounds have been included as well as other humic substances, and a generally similar solubilization behaviour has been found (Misra et al. 1996; Shaw et al. 2000; Loffredo et al. 1999).

A number of different types of ionic interactions have been reported between humic substances and organic compounds. In the simplest case, the organic compound exists in solution as cations that can be bound by carboxylate groups of humic substances. Amino acids and triazine herbicides would bind to humic substances by this mechanism at low $\mathrm{pH}$ values where the nitrogen containing groups would be protonated, but hydrogen bonding can also take place between humic substances and basic herbicides such as substituted urea herbicides (Kam and Gregory 2001). The groups most likely to enter into hydrogen-bonding interactions would be hydroxyl and carboxylic acid groups on the surfaces of the humic substance membrane-like aggregates (Kḷaviņš 1998).

\section{Impact of humic substances on metabolic processes in plants}

The suggestion that HS can have a direct effect on plant metabolism, considers that these substances are taken up into plant tissues (Vaughan and Malcom 1985). As far as they have a poly-anionic (acid) nature, HS could simply act as surface-active molecules (Nardi et al. 1991). By decreasing the $\mathrm{pH}$ at the surface of the plasma membranes of root cells, HS may counteract the alkalinization which occurs when $\mathrm{NO}_{3}{ }^{-}$is used as an $\mathrm{N}$ source (Raven and Smith 1976).

The plasma membranes of plant cells possess several redox activities that can be related to both plant nutrition and cell wall formation and lignification. In this context, it has been shown that, in oat roots, HS inhibited NADH oxidation in either the presence or absence of an artificial electron acceptor (ferricyanide) (Pinton et al. 1995).

There are many reports showing that HS, extracted from a wide range of soils, were able to enhance respiration of higher plants (Vaughan and Malcom 1985), with the effects of FA more pronounced than that of HA. These results have been interpreted in varying ways. At first, humic substances can act as substrates or respiratory chain catalysts, but they can also stimulate the peroxidase (Muscolo et al. 1993). A second aspect that has been examined concerns photosynthesis. Even in this case, our information is fragmentary and not very recent. Although indirect, the most prominent effect of HS application to growing plants was an increase of chlorophyll 
content which, in turn, could affect photosynthesis (Sladky 1959). However, the increase of chlorophyll alone did not necessarily result in higher yields. HS, applied to the growth solution, stimulated enzyme activities related to the photosynthetic sulphate reduction pathway. This positive effect of HS has also been observed on the main photosynthetic metabolism in maize leaves, where a decrease in starch content was accompanied by an increase of soluble sugars (Merlo et al. 1991). This change appeared to be mediated by variations of the activity of the main enzymes involved in carbohydrate metabolism.

\section{Applications of humic substances in agriculture}

Composts originating from animal manures, sewage sludge or paper-mill sludge have been shown to contain large amounts of humic substances (Garcia et al. 1995; Maggioni et al. 1987; Valdrighi et al. 1996). Studies of the positive effects of these humic substances on plant growth, when full requirements for mineral nutrition have been met, have resulted in consistently positive effects on growth independent of nutrition (Chen and Aviad 1990). For instance, in controlled experiments, humic substances increased dry matter yields of corn and oat seedlings; numbers and lengths of tobacco roots (Mylonas and Mccants 1980); dry weights of shoots, roots, and nodules of soybean, peanut, and clover plants (Tan and Tantiwiramanond 1983); vegetative growth of chicory plants (Valdrighi et al. 1996); and induced shoot and root formation in tropical crops grown in tissue culture (Goenadi and Sudharama 1995). The typical growth response curves that have been reported to result from treating plants with humic substances show progressively increased growth with increasing concentrations of humic substances, but there is usually a decrease in growth at higher concentrations of the humic materials (Chen and Aviad 1990). Hypotheses accounting for this stimulatory effect of humic substances at low concentrations are numerous, the most convincing of which suggests a "direct" action on the plants, which is hormonal in nature, together with an "indirect" action on the metabolism of soil micro-organisms, the dynamics of uptake of soil nutrients, and soil physical conditions (Casenave de Sanfilippo et al. 1990; Chen and Aviad 1990; Muscolo et al. 1993, 1996, 1999). Other mechanisms which have been suggested to account for promotion of plant growth by humic substances include: enhanced uptake of metallic ions and increases in cell permeability (Chen and Aviad 1990).

During the last decade, the biological activities of humic substances, particularly those derived from earthworm faeces, have begun to be investigated. Dell'Agnola and Nardi (1987) reported hormone-like or plant-growth regulator effects, of depolycondensed humic fractions obtained from the faeces of the earthworms Apporectodea rosea (Eisen) and Apporectodea caliginosa (Sav), on plants. Nardi et al. (1988) reported that humic materials produced in the faeces of A. rosea and A. caliginosa exhibited auxin-, gibberellin-, and cytokinin-like activities. Treating carrot cells with humic substances obtained from the faeces of the earthworm A. rosea 
increased their growth and induced morphological changes similar to those produced by auxins (Muscolo et al. 1999).

In a recent study (Atiyeh et al. 2002) some effects of humic acids, formed during the breakdown of organic wastes by earthworms (vermicomposting), on plant growth were evaluated. The incorporation of vermicompost derived humic acids, into either type of soilless plant growth media, increased the growth of tomato and cucumber plants significantly, in terms of plant heights, leaf areas, shoot and root dry weights. Plant growth increased with growing concentrations of humic acids incorporated into the medium up to a certain proportion, but this differed according to the plant species, the source of the vermicompost, and the nature of the container medium. Plant growth tended to be increased by treatments of the plants with $50-500 \mathrm{mg} / \mathrm{kg}$ humic acids, but often decreased significantly when the concentrations of humic acids derived in the container medium exceeded $500-1000 \mathrm{mg} / \mathrm{kg}$. These growth responses were most probably due to the hormone-like activity of humic acids from the vermicomposts or could have been due to plant growth hormones adsorbed onto the humates.

\section{Conclusions}

In contrast to the highly specialized and individualized roles of molecules in biological processes, the functions of HS in the environment do not necessitate the participation of specific molecules. The functions of HS in the soil environment (such as pH-buffering, binding of clay particles, serving as a reservoir for various micronutrient metal ions, sequestration and transport of metal ions, retaining moisture, etc.) are less specific than those in biological systems. In fact, the general functions of HS in the soil could, in principle, be satisfied by many of the direct, unaltered products of living cells such as proteins, poly-saccharides, or poly-nucleotides. The molecular heterogeneity that is characteristic of HS serves a vital role in the ecological system. Humic substances constitute the only natural organic material that can survive in bulk and still possess the requisite chemical reactivity to perform the various functions for sustaining soil quality and promoting plant growth.

It is clear from the above that HS may positively influence higher plant metabolism. Still, the yet unknown nature of HS prevents us from drawing more conclusive results concerning the effects of HS on plant growth. We can only consider that HS appear to influence the metabolism of plant cells at different levels. Their effects may, therefore, be different and be additive, overlapping, or, in some cases, mechanistic related. This apparently puzzling situation can be, however, rationalized by hypothesizing that HS have several targets that can be explained partly by their chelating capacity and partly by their hormone-like activity. This is not surprising, considering the complex and differentiated nature of HS. Therefore, more research is necessary to explain the positive effects of HS on higher plants. In particular these studies have to be, primarily, focused on the following topics: (1) the availability of humus in the soil solution and in the rhizosphere; (2) the link between humus activity 
and the presence in the soil solution of active metabolites of various microbes; and (3) the use of more characterized HS in experiments on plant metabolism.

\section{Acknowledgement}

This study was supported by the Latvia Science Council project "Properties and structure of peat humic substances and possibilities of their modification" (lzp-2018/1-0009).

\section{Kopsavilkums}

Rakstā aplūkotas nozīmīgākās augsnes un kūdras galvenās organiskās sastāvdaḷas - humusvielu īpašības atkarībā no to izdalīšanas apstākliem, izcelsmes, kā arī to iespējamie struktūras modeḷi. Izvērtēts humusvielu iespējamās darbības modelis uz augiem, kas varētu būt pamatā humusvielu saturošu preparātu izmantošanai augu augšanas nodrošināšanai un stimulēšanai.

\section{References}

Aiken, G.R., McKnight, D.M. and Wershaw, R.L. (1985). Humic substances in soil, sediment, and water. Geochemistry, Isolation and Characterization. New York: Wiley.

Alvarez, E.A., Mochon, M.C., Sanchez, J.C.J. and Rodriguez, M.T. (1998). Heavy metal extractable forms in sludge from wastewater treatment plants. Chemosphere, 47, 765-775.

Atiyeh, R.M., Lee, S., Edwards, C.A., Arancon, N.Q. and Metzger, J.D. (2002). The influence of humic acids derived from earthworm-processed organic wastes on plant growth. Bioresource Technology, 84, 7-14.

Casenave de Sanfilippo, E., Arguello, J.A., Abdala, G., and Orioli, G.A. (1990). Content of Auxin-, inhibitor- and Gibberellin-like substances in humic acids. Biologia Plantarum, 32, 346-351.

Chen, Y. and Aviad, T. (1990). Effects of humic substances on plant growth. In: MacCarthy, P., Clapp, C.E., Malcolm, R.L. and Bloom, P.R. (eds.) Humic Substances in Soil and Crop Sciences: Selected Readings. Madison, Wisconsin: ASA and SS SA, 161-186.

Chiou, C.T., Porter, P.E., and Schmedding, D.W. (1983). Partition equilibria of nonionic organic compounds between soil organic matter and water. Environmental Science \& Technology, 17, 227-231.

Clapp C.E., Liu R., Cline V.W., Chen Y. and Hayes M.H.B. (1998). Humic substances for enhancing turfgrass growth. In: Davies, G. and Ghabour, E.A. (eds.) Humic substances: structures, properties and uses, London: RSC, 227-233.

Dell'Agnola, G. and Nardi, S. (1987). Hormone-like effect and enhanced nitrate uptake induced by depolycondensed humic fractions obtained from Allobophora rosea and A. caliginosa faeces. Biology and Fertility of Soils, 4, 115-118.

Francko, D.A. (1986). Epilimnetic phosphorus cycling: influence of humic materials and iron on co-existing major mechanisms. Canadian Journal of Fisheries and Aquatic Sciences, 43, 302-310.

Florence, T. M. and Batley, G. E. (1980). Chemical speciation in natural waters. Critical Reviews in Analytical Chemistry, 9, 219-296.

Garcia, C., Ceccanti, B., Masciandaro, G. and Hemandez, T. (1995). Phosphatase and pglucosidase activities in humic substances from animal wastes. Bioresource Technology, 53, 79-87.

Goenadi, D.H. and Sudharama, I.M. (1995). Shoot initiation by humic acids of selected tropical crops grown in tissue culture. Plant Cell Reports, 15, 59-62.

Hayes, M.H.B. and Clapp, C.E. (2001). Humic substances: considerations of compositions, aspects of structure and environmental influences. Soil Science, 166 (11), 723-737.

Jarvis, S.C. (1981). Copper sorption by soils at low concentrations and relation to uptake by plants. Journal of Soil Science, 32, 257-269.

Jones, M.N. and Bryan, N.D. (1998). Colloidal properties of humic substances. Advances in Colloid and Interface Science, 78, 1-48. 
Kam, S.K. and Gregory, J. (2001). The interaction of humic substances with cationic polyelectrolytes. Water Research, 35 (15), 3557-3566.

Kḷaviņš, M. (1998). Aquatic humic substances. Rīga: LU.

Kḷaviņš, M., Seržāne, J. and Babre, K. (1999). Catalytic activity of humic substances in degradation and transformation of xenobiotics: hydrolysis reactions of p-nitrophenylacetate. Latvijas Kīmijas Žurnāls, 1, 87-92.

Loffredo, E., D’Orazio, V., Brunetti, G. and Senesi, N. (1999). Adsorption of chlordane onto humic acids from soils and pig slurry. Organic Geochemistry, 30, 443-451.

MacCarthy, P. (2001). The principles of humic substances. Soil Science, 166 (13), 738-751.

Maggioni, A., Varanini, Z., Nardi, S. and Pinton, R. (1987). Action of soil humic matter on plant roots: stimulation of ion uptake and effects on $\left(\mathrm{Mg}^{+2} \mathrm{~K}^{+}\right)$ATPase activity. Science of the Total Environment, 62, 355-363.

Merlo, L, Ghisi, R., Rascio, N. and Passera, C. (1991). Effects of humic substances on carbohydrate metabolism of maize leaves. Canadian Journal of Plant Science, 71, 419-425.

Misra, V., Pandey, S.D. and Viswanathan, P.N. (1996). Binding of gammahexachlorocyclohexane with humic acid and chlorophyll in aquatic environment in relation to ecotoxicity. International Journal of Environmental Analytical Chemistry, 64, 257-264.

Muscolo, A., Bovalo, F., Gionfriddo, F. and Nardi, S. (1999). Earthworm humic matter produces auxin-like effects on Daucus cardia cell growth and nitrate metabolism. Soil Biology and Biochemistry, 31, 1303-1311.

Muscolo, A., Felici, M., Concheri, G. and Nardi, S. (1993). Effect of earthworm humic substances on esterase and peroxidase activity during growth of leaf explants of Nicotiani plumbaginifolia. Biology and Fertility of Soils, 15, 127-131.

Muscolo, A., Panuccio, M.R., Abenavoli, M.R., Concheri, G. and Nardi, S. (1996). Effect of molecular complexity and acidity of earthworm faeces humic fractions on glutamate dehydrogenase, glutamine synthetase, and phosphenolpyruvate carboxylase in Daucus cardia IX II cell. Biology and Fertility of Soils, 22, 83-88.

Mylonas, V.A. and Mccants, C.B. (1980). Effects of humic and fulvic acids on growth of tobacco. I. Root initiation and elongation. Plant and Soil, 54, 485-490.

Nardi, S., Arnoldi, G. and Dell' Agnola, G. (1988). Release of the hormone-like activities from Allolobophora rosea and A. caliginosa faeces. Canadian Journal of Soil Sciences, 68, 563-567.

Nardi, S., Concheri, G. and Dell'Agnola, G. (1996). Biological activity of humic substances. In: Piccolo, A., (ed.) Humic Substances in Terrestrial Ecosystems. Amsterdam: Elsevier, 361-406.

Nardi, S., Concheri, G., Dell'Agnola, G. and Scrimin, P. (1991). Nitrate uptake and ATPase activity in oat seedlings in the presence of two humic fractions. Soil Biology and Biochemistry, 23, 833-836.

Nardi, S., Pizzeghello, D., Reniero, F., Rascio, N. (2000). Chemical and biochemical properties of humic substances isolated from forest soils and plant growth. Soil Science Society of America Journal, 64, 639-645.

Nardi, S., Pizzeghello, D., Muscolo, A. and Vianello A. (2002). Physiologial effects of humic substances on higher plants. Soil Biology and Biochemistry, 34, 1527-1536.

Orlov, D.S. (1990). Soil humic acids and general humification theory. Moscow: MGU.

Piccolo, A., Nardi, S. and Concheri, G. (1992). Structural characteristics of humus and biological activity. Soil Biology and Biochemistry, 24, 273-380.

Pinton, R., Cesco, S., Santi, S. and Varanini, Z. (1995). Effect of soil humic substances on surface redox activity of oat roots. Journal of Plant Nutrition, 18, 2111-2120.

Pizzeghello, D., Nicolini, G. and Nardi, S. (2001). Hormone-like activity of humic substances in Fagus sylvatica forests. New Phytologist, 151, 647-657.

Raven, J.A. and Smith, F.A. (1976). Nitrogen assimilation and transport in vascular land plants in relation to intracellular $\mathrm{pH}$ regulation. New Phytologist, 76, 415-431. 
Schnitzer, M. and Khan, S.U. (1972). Humic substances in the environment. New York: Marcel Dekker.

Schulten, H.R. and Schnitzer, M. (1993). A state of the art structural concept for humic substances. Naturwissenschaften, 80, 29-30.

Senesi, N., Sposito, G. and Martin, J.P. (1986). Copper(II) and iron(III) complexation by soil humic acids: and IR and ESR study. Science of the Total Environment, 55, 851-362.

Shaw, L.J., Beaton, Y., Glover, L.A., Killham, K., Osborn, D. and Meharg, A.A. (2000). Bioavailability of 2,4-dichlorphenol associated with soil water-soluble humic material. Environmental Science \& Technology, 34 (22), 4721-4726.

Sladky, Z. (1959). The effect of extracted humus substances on growth of tomato plants. Biologia Plantarum, 1, 142-150.

Stevenson, F.J. (1991). Organic matter-micronutrient reactions in soil. In: Mortvedt, J.J., Cox, E.R., Shuman, L.M., Welch, R.M. (eds.) Micronutrients in Agriculture. Madison: Soil Science Society of America, 145-186.

Stevenson, F.J. (1994). Humus Chemistry: Genesis, Composition, Reactions, Second Edition. New York: Wiley, 496.

Tan, K.H. and Tantiwiramanond, D. (1983). Effect of humic acids on nodulation and dry matter production of soybean, peanut, and clover. Soil Science Society of America Journal, 47, 1121-1124.

Tipping, E. (1986). Some aspects of the interactions between particulate oxides and aquatic humic substances. Marine Chemistry, 18, 161-169.

Tipping, E. (1994). WHAM - a chemical equilibrium model and computer code for waters, sediments and soils incorporating a discrete site/electrostatic model of ion-binding by humic substances. Computers \& Geosciences, 20 (6), 973-1023.

Valdrighi, M.M., Pera, A., Agnolucci, M., Frassinetti, S., Lunardi, D. and Vallini, G. (1996). Effects of compost-derived humic acids on vegetable biomass production and microbial growth within a plant (Cichorium intybus)-soil system: a comparative study. Agriculture, Ecosystems and Environment, 58, 133-144.

Varanini, Z., Pinton, R. (1995) Humic substances and plant nutrition. In: Liittge, U. (ed.) Progress in Botany 56. Berlin: Springer, 97-117.

Varanini, Z. and Pinton, R. (2001). Direct versus indirect effects of soil humic substances on plant growth and nutrition. In: Pinton, R., Varanini, Z. and Nannipieri, P. (eds.) The Rizosphere. Basel: Marcel Dekker, 141-158.

Vaughan, D. and Malcom, R.E. (1985). Influence of humic substances on growth and physiological processes. In: Vaughan D. and Malcom R.E. (eds.) Soil Organic Matter and Biological Activity. Dordrechts: Martinus Nijhoff Junk W., 37-76.

Vaughan, D. and Ord, E.G. (1981). Uptake and incorporation of ${ }^{14} \mathrm{C}$-labelled soil organic matter by roots of Pisum. sativum L. Journal of Experimental Botany, 32, 679-687.

Visser, S.A. (1987). Effect of humic substances on mitochondrial respiration and oxidative phosphorylation. The Science of the Total Environment, 62, 347-354.

Wershaw, R.L. (1989). Application of a membrane model to the sorptive interactions of humic substances. Environmental Health Perspectives, 83, 191-203.

Wershaw, R.L. (1993). Model for humus. Environmental Science \& Technology, 27 (5), 814 817.

Wershaw, R.L., Bulcar, P.J. and Goldberg, M.C. (1969). Interaction of pesticides with natural organic material. Environmental Science \& Technology, 3, 271-273.

Wershaw, R.L. \& Pinckney, D.J. (1973). Determination of the association and dissociation of humic acid fractions by small angle X-ray scattering. Journal of Research of the U.S. Geological Survey, 1, 701-707.

Winner, R.W. (1984). The toxicity and bioaccumulation of cadmium and copper as affected by humic acid. Aquatic Toxicology, 5, 267-274. 